\title{
Caracterización técnica, social y comercial de las explotaciones ovinas manchegas, centro-sur de España
}

\section{Technical, social and commercial profile of the Manchega dairy sheep farms in South-Central Spain}

\author{
José Rivasa, Antón Garcíab, Paula Toro-Mujicac, Elena Angónb, José Pereab, Martiña \\ Morantes d, Rafaela Dios-Palomarese
}

\begin{abstract}
RESUMEN
Las explotaciones de ovino de raza Manchega vinculadas a la denominación de origen protegido "Queso Manchego" son caracterizadas por aspectos técnicos, sociales y comerciales. A partir de una muestra aleatoria, estratificada y proporcional de 157 explotaciones, la información se obtuvo mediante encuesta directa al productor. La caracterización se realizó mediante análisis descriptivos. La muestra se estratificó en base al número de ovejas y uso de tecnología. Los grupos se compararon mediante un ANOVAC multifactorial. La explotación media responde a un sistema extensivo mixto agricultura-ganadería, de tipo pastoril (85\%), con 888 ovejas y 1,124 ha de superficie total (ST), el $18 \%$ de la ST se usa en agricultura, el resto es pasto natural. El productor tiene 48 años en promedio, existe esperanza de continuidad en la actividad $(91 \%)$, y de relevo generacional $(74 \%)$. La comercialización se realiza en un $91 \%$ por los canales comerciales tradicionales, y sólo en un $9 \%$ por los canales alternativos. El mayor desafío se asocia a los altos precios de los insumos y el precio de los productos. Las ventajas competitivas de las explotaciones la constituyen; por una parte el bajo nivel de inversiones y la realización de una actividad agrícola de baja producción, aspectos que le confieren flexibilidad. A partir de la estratificación por dimensión y uso de tecnología se establecen diferentes modelos productivos destacando explotaciones pequeñas y grandes con bajo uso de tecnologías, y grandes con elevado uso de tecnología.
\end{abstract}

PALABRAS CLAVE: Sistema mixto, Bajos insumos, Oveja Manchega, Caracterización, Tecnología.

\begin{abstract}
Manchega sheep farms are characterized by technical, social and commercial aspects of the protected designation of origin "Queso Manchego". The data was obtained through surveys with stratified random sampling and proportional allocation, representing $\mathbf{1 7 . 2 5} \%$ of the population. The characterization was obtained by analysis of descriptive statistics. Groups were formed based on the size and use of technology and compared using a multivariate ANOVAC. The typical farm responds to a mixed crop-livestock extensive system of pastoral type (85\%), with 888 sheep and 1,124 ha total area, $18 \%$ of this area is used in agriculture, mainly grain and forage, the rest of the ST is natural grass, fallow land and wastelands which are used by grazing. The farmer is $\mathbf{4 8}$ yr old, married, with one child; there is hope for continuity in the activity $(91 \%)$, and generational handover $(74 \%)$. The marketing is done by $91 \%$ for long or traditional commercial channels and only $9 \%$ for short or alternative channels ( $9 \%)$. The greater challenge is associated with high input prices and low product prices. The competitive advantages of the farms are on the one hand the low level of investment and the realization of low-yield farming, aspects that give it flexibility. From the groups by size and technology use different production models emphasizing small and large farms with low use of technologies and large with high use of established technology.
\end{abstract}

KEY WORDS: Mixed system, Low inputs, Manchega sheep, Characterization, Technology.

Recibido el 24 de febrero de 2014. Aceptado el 24 de marzo de 2014.

a Departamento de Producción Animal, Facultad de Ciencias Veterinarias. Universidad Central de Venezuela. Avenida Universidad vía el Limón, 2101, Maracay, Venezuela. rivasjoseh@gmail.com. Correspondencia al primer autor.

b Facultad de Veterinaria. Universidad de Córdoba, Campus de Rabanales, Córdoba, España.

c Pontificia Universidad Católica de Chile. Santiago. Chile.

d Facultad de Agronomía, Universidad Central de Venezuela. Maracay, Venezuela.

e Departamento de Estadística, Universidad de Córdoba, Córdoba España. 


\section{INTRODUCCIÓN}

La Mancha es una Comarca natural de CastillaLa Mancha, dispone del $15.8 \%$ del censo ovino de España y aporta cerca del $21 \%$ de la producción de leche de oveja(1). El censo de ovejas de raza Manchega asciende a 556,363 reproductoras distribuidas en 910 explotaciones(2).

La Comarca la Mancha forma parte de las denominadas zonas desfavorecidas del sur de Europa(3), en razón de su despoblamiento, tendencia a la regresión de la población y baja productividad de sus tierras. La oveja Manchega es la base de la Denominación Origen Protegida (DOP) "Queso Manchego", condición que beneficia la conservación de la raza y el desarrollo de la economía agrícola en las denominadas zonas desfavorecidas. Esto tiene importancia no sólo para mantener la actividad agrícola que de otra manera estaría destinada al abandono, sino también para la expansión de las empresas productoras y procesadoras de productos lácteos( $(4)$.

Los sistemas evolucionan y se modifican con el tiempo, por lo que estudios anteriores no son aplicables actualmente como herramientas en la toma de decisiones $(5,6)$, ni los realizados en ovino ecológico $(7,8)$. La explotación ovina tradicional aprovecha los pastos naturales, residuos de cosechas y rastrojera; y es complementaria a un sistema agrícola de producción de cereales en secano, conocido como sistema mixto ovino-cereal. Con la incorporación de España a la Unión Europea en 1986 y a la Política Agrícola Común (PAC), se impulsaron cambios en el sistema ovino-cereal, manifiestos en una baja integración entre las dos actividades y en tres tipos de explotaciones: sin tierra; con escasa superficie y grandes extensiones de escasa productividad(5).

La reforma de la PAC de 2003, y la revisión del $2008-2009$, junto a la volatilidad de los precios de las materias primas, la crisis económica entre otros factores, orientaron las explotaciones

\section{INTRODUCTION}

La Mancha is a natural region of Castilla-La Mancha, it has $15.8 \%$ of the sheep Spain census and contributes about $21 \%$ of sheep's milk production(1). The census of Manchega breed sheep includes 556,363 breeding females spread over 910 farms(2).

La Mancha region is part of the so-called lessfavoured areas in the South of Europe(3), due to its depopulation, a trend in a decrease the population and low productivity of their lands. The Manchega sheep is the basis of the protected origin designation (POD) "Queso Manchego", condition that benefits the conservation of the breed and the development of the agricultural economy in these so-called lessfavoured areas. This aspect is important not only to maintain the agricultural activity that otherwise would be destined to the abandonment, but also for the expansion of producers and dairy products processing companies(4).

Systems evolve and change over time, so previous studies are not applicable at present as tools for decision-making $(5,6)$, neither for organic sheep $(7,8)$. The traditional sheep farming takes advantage of the natural grasses and crop residues; it is complementary to an agricultural system of cereal production in rainfed, known as cereal-sheep mixed system. The entry of Spain into the Europe Union in 1986 and to the Common Agricultural Policy (CAP), produced changes in the sheep-cereal system, manifest in a low integration between the two activities and three types of farms: landless, with scarce area and large areas of low-productivity(5).

The 2003 CAP reform, and the review of 20082009 , together with the volatility of the prices of raw materials, and the economic crisis among other factors, oriented farming towards a progressive intensification $(8,9,10)$, with the aim of reaching greater productivity, reduce costs and balance the loss of competitiveness of traditional systems(11). The key actions of the 
ganaderas hacia una progresiva intensificación $(8,9,10)$, con el objetivo de lograr mayor productividad, reducir costos y compensar la pérdida de la competitividad de los sistemas tradicionales(11). Las acciones clave de la PAC conllevan la disminución del pastoreo, incremento de la tecnología y la dimensión, uso de mano de obra calificada y razas mejoradas $(8,12)$.

Los productos con DOP representan una forma de proteger y hacer hincapié en un patrimonio productivo histórico, originario de una área específica, que se obtiene a partir de una cultura rural, y ofrece características originales(4). Estos productos, poseen calidad diferenciada, lo que constituye una herramienta de redistribución del valor añadido a lo largo de la cadena de producción(13), potencia los beneficios del mercado, atrae consumidores, favorecen el desarrollo del medio rural, la protección del medioambiente, y la sostenibilidad en el uso de los factores de producción(4).

En este sentido, el futuro de las explotaciones depende, en gran medida, del mantenimiento del sistema mixto cereal-ovino, base de la DOP, y por tanto conocer la estructura productiva actual desde una perspectiva global constituye el primer paso para diagnosticar las deficiencias y fortalezas del sistema.

El objetivo de este trabajo es la caracterización de las explotaciones de ovino raza Manchega vinculadas a la DOP "Queso Manchego" en relación con variables técnicas, sociales y comerciales; conocimiento que permita determinar y proponer medidas correctoras que favorezcan la mejora de la competitividad y viabilidad de las explotaciones ante los nuevos escenarios y retos existentes.

\section{MATERIALES Y MÉTODOS}

El área de estudio fue la Comarca Natural de la Mancha, con una extensión de 30,000 km² conformada por parte de las provincias de Albacete, Ciudad Real, Cuenca y Toledo. El clima es Mediterráneo continental, con fuertes
CAP entailed reduced grazing, increased technology and the dimension, use of skilled labor and improved breeds $(8,12)$.

PDO products represent a form of protection and emphasize a productive historical heritage, originated in a specific area, emerged from a rural culture, and provider of original features(4). These products have different quality, and this serve as a tool of redistribution of added value along the production chain(13), that focuses in the benefits of the market power, attracts consumers, promotes the development and protection of the rural environment, and it also assures sustainability in the use of the production factors(4).

In this sense, the future of farms depends, largely, on the maintenance of the sheep-cereal system, base of the PDO, and therefore knowing the current productive structure from a global perspective is the first step to diagnose the strengths and lacks of such system.

The objective of this work is the characterization of the Manchega sheep farms linked to the PDO "Queso Manchego-" in relation to technical, social and commercial variables. It will offer the required knowledge that allows to determine and propose corrective measures that favor the improvement of the competitiveness and viability of farms to the new scenarios and challenges.

\section{MATERIALS AND METHODS}

The study area was the natural region of La Mancha, with an extension of $30,000 \mathrm{~km}^{2}$ formed by the provinces of Albacete, Ciudad Real, Cuenca and Toledo. The climate is Mediterranean continental, with strong temperature fluctuations and notable aridity. Annual rainfall is between 300 and $400 \mathrm{~mm}$, mostly in spring and autumn(6).

A stratified random sampling design by provinces with proportional allocation(14), was used in accordance with the methodology proposed by the Food and Agricultural Organization (FAO). 
oscilaciones térmicas y notable aridez. Las precipitaciones se sitúan entre los 300 y 400 $\mathrm{mm}$ anuales, siendo éstas más frecuentes en primavera y otoño(6).

Se utilizó un diseño de muestreo aleatorio estratificado por provincias con asignación proporcional(14), de acuerdo con la metodología propuesta por la Organización para la Agricultura y la Alimentación (FAO). Se estudiaron 157 explotaciones, lo que equivale al $17.25 \%$ de la población de ovejas Manchegas, incluida en el catálogo oficial de razas de ganado de España como raza autóctona de fomento(2). La recolección de la información se llevó a cabo durante el año 2012.

Se analizaron 38 variables representativas de la estructura técnica, social y comercial de las explotaciones. La muestra se estratificó según la dimensión (número de ovejas) y uso de tecnologías. El número de ovejas se estratificó en dos categorías: explotaciones pequeñas (EPQ) y grandes (EGD), en base a la distribución de frecuencias y el percentil $50\left(P_{50}=806\right)$. En cuanto a las tecnologías se clasificaron a partir de las 37 variables tecnológicas identificadas, distribuidas: nueve de gestión y prácticas de manejo, tres de alimentación, siete de reproducción y genética, ocho de sanidad y calidad de la leche, cuatro de recursos naturales y seis de equipos e instalaciones. Se establece con la distribución de frecuencias y el percentil $50\left(P_{50}=17\right)$ dos grupos de uso de tecnología; explotaciones con uso medio de tecnología (EUMT) y con uso alto de tecnología (EUAT)(15). Mediante prueba $t$ se comprobó la diferencia entre los grupos obtenidos $(P<0.01)$.

En la identificación de los problemas se utilizó una escala de Likert (1 totalmente en desacuerdo a 5 totalmente de acuerdo). Los datos obtenidos se analizaron con el programa estadístico SPSS versión 15.0(16). Se aplicaron análisis de estadística descriptiva, la comparación entre grupos se hizo mediante un ANOVA multifactorial de efecto fijo sin interacción debido a que en análisis previos la interacción resultó
The study comprised 157 farms, means a $17.25 \%$ of the manchega sheep population, which is included in the official catalog of livestock breeds of Spain as a promotion breed(2). The data collection took place during the year 2012.

Thirty eight (38) variables representative of the technical, social and commercial structure of farms were analyzed. The sample was stratified according to the size (number of sheep) and use of technologies. The number of sheep was stratified into two categories: small farms (SF) and large (LF), based on the distribution of frequencies and the 50 percentile $\left(P_{50}=806\right)$. The technologies were classified according to the 37 variables identified, distributed as follows: nine from management, three form feeding, seven of reproduction and genetics, eight of health and milk quality, four of natural resources and six from equipment and facilities. Two groups of technology were established with the distribution of frequencies and the 50 percentile $\left(P_{50}=17\right)$ : farms with medium use of technology (FMUT) and high use of technology (FHUT)(15). The $\mathrm{t}$ test proved the difference among the values obtained in the groups $(P<0.01)$.

A Likert scale was used in the identification of problems (1 completely disagree to 5 totally agree). Data obtained were analyzed with the SPSS statistical program version 15.0(16). Applied analysis of descriptive statistics, for comparison among groups was made by a multifactorial ANOVA fixed effect without interaction due to the fact that in previous analyses the interaction was not significant $(P>0.05)$. The Tukey test for comparison of means in the quantitative variables, as well as tables of contingency and $\mathrm{X}^{2}$ in the qualitative variables test were used(17).

\section{RESULTS AND DISCUSSION}

\section{Manchega ovine system}

The means exploitation responds to an extensive mixed crop-livestock system, pastoral type (85 \%) of large size (Table 1). Agriculture is 
no significativa $(P>0.05)$. Se empleó la prueba de Tukey para la comparación de medias en las variables cuantitativas, además de tablas de contingencia y la prueba de $\mathrm{X}^{2}$ en las variables cualitativas(17).

\section{RESULTADOS Y DISCUSION}

Sistema ovino manchego

La explotación media responde a un sistema extensivo mixto agricultura-ganadería, de tipo pastoril (85\%), de gran dimensión (Cuadro 1). El $18 \%$ de la superficie total (ST) se usa en la agricultura, principalmente cereales y forrajes, aunque se combina frecuentemente con otros cultivos (viña, olivar, etc.), el resto de la superficie son pastos naturales, eriales y barbechos aprovechados en pastoreo.

La explotación media genera 3.3 unidades de trabajo anual (UTA), resultado mayor al reportado en los sistemas ovinos de la Dehesa(11) y en las explotaciones ovinas en el noroeste de España(18). El $58 \%$ de la mano de obra es familiar, lo cual concuerda con estudios realizados en Castilla-La Mancha $(8,19)$, indicando el carácter familiar de la explotación típica, con una productividad de la mano de obra, de 45 unidades de ganado mayor (UGM) used in $18 \%$ of the total area (TA), mainly cereals and forages, although it is often combined with other crops (vine, olive grove, etc.); the rest of the area are wastelands, natural pastures and fallow land used under grazing conditions.

The medium exploitation generates 3.3 annual work units (AWU), result higher than that reported in the "Dehesa"(11) and sheep farms in the Northwest of Spain(18). Fifty eight (58) percent of the workforce is familiar, which is consistent with studies in Castilla-La Mancha $(8,19)$, indicating the family nature of the typical exploitation, with a productivity of the labor force of 45 animal units (AU) by AWU, a result that indicates a low labor force use $(8,20)$.

The average stocking rate is $0.19 \mathrm{AU} / \mathrm{ha}$ as consequence of the limited nutritional contribution of the grazing area(21) and structural constraints(5). The stocking is sensitive to exploitation area, soil conditions, climate and the ability of farmers to obtain the maximum production of resources(11), but it limits its efficient management, the type and land tenure, conditions that do not allow a more active role of farmers on agricultural activity(5).

Dependence on external food is $60 \%$, product of the greatest number of animals, and an

Cuadro 1. Características técnicas de las explotaciones de ovino de raza Manchega

Table 1. Technical characteristics of Manchega breed sheep

\begin{tabular}{lccc}
\hline Variable & Unit & Mean \pm SE & CV (\%) \\
\hline Sheep & $\mathrm{n}$ & $888.0 \pm 50.0$ & 92.0 \\
Total area & ha & $1123.9 \pm 101.5$ & 121.7 \\
Milk & L/ewe/year & $130818.0 \pm 7.450 .6$ & 94.6 \\
Comercial lambs & lambs/ewe/year & $1209.9 \pm 71.9$ & 94.4 \\
Lamb mortality & $\%$ & $10.4 \pm 0.56$ & 67.1 \\
Milk/ewe/day & liters & $1.1 \pm 0.03$ & 31.5 \\
Lambing/ewe/year & $\mathrm{n}$ & $1.1 \pm 0.02$ & 19.3 \\
Prolificity & lambs/farrowing & $1.4 \pm 0.02$ & 16.4 \\
Lambing interval & days & $341.4 \pm 5.6$ & 20.7 \\
Concentrate/sheep/day & kg & $0.80 \pm 0.05$ & 75.2 \\
\hline SE= Standard error; CV= Coeficient of variability. & &
\end{tabular}


por UTA, resultado que indica un bajo aprovechamiento de la mano de obra $(8,20)$.

La carga ganadera media es de 0.19 UGM/ha como consecuencia del limitado aporte nutricional del área de pastoreo(21) y de las limitaciones estructurales(5). La carga ganadera es sensible a la superficie de la explotación, condiciones del suelo, clima y la habilidad del ganadero para obtener la máxima producción de los recursos(11), pero limita su manejo eficiente el tipo y tenencia de la tierra, condiciones que no permiten un papel más activo de los ganaderos sobre la actividad agrícola(5).

La dependencia de alimentos externos es del $60 \%$, producto del mayor número de animales, y una actividad agrícola de baja producción, por lo que se requieren más insumos alimenticios externos, similar a lo reportado en ovinos lecheros del noroeste de España(18). En el $61 \%$ de las granjas la alimentación consiste en el suministro en pesebre para las ovejas en producción, de una mezcla de forrajes y subproductos industriales (unifeed), que se complementa con el aporte de concentrado, sin realizar racionamiento según nivel de producción. La tasa de reposición en promedio es del $27 \%$, lo que indica una renovación elevada de animales, principalmente para incrementar la intensificación del sistema. La edad de incorporación de las hembras a la primera cubrición es de 9 meses, similares a los señalados en ovino ecológico en Castilla-La Mancha(8) y otros sistemas de producción tecnificados con ovinos en Castilla León(18), no obstante difieren de los sistemas extensivos con ovinos en la Dehesa(11). La reproducción se planifica en el $82 \%$ de las explotaciones y consta en promedio de tres cubriciones, mientras que el resto mantiene los moruecos con las ovejas permanentemente, permitiendo la monta continua y no controlada durante todo el año. Los productores se plantean un objetivo reproductivo de 1.5 parto/oveja/año, con un resultado de 1.1 parto/oveja/año (73\%), este indicador permite simplificar y unificar agricultural activity of low production, so it will require of more external food inputs, similar to that reported in dairy sheep in the Northwest of Spain(18). In a $61 \%$ of the farms, food consists of the supply in corral for the sheep in production of a mixture of forage and industrial by-products (unifeed), which is complemented by the contribution of concentrate, without rationed according to the production level.

The average replacement rate is $27 \%$, indicating a high renewal of animals, mainly to increase the intensification of the system. The age of females incorporation to the first mating is $9 \mathrm{mo}$, similar to those listed in ecological sheep $(8)$ and other production systems with sheep in Castilla León(18), but they differ from the extensive systems with sheep in the meadow(11). The reproduction is planned in $82 \%$ of farms and consists on average of three season matings, while the rest holds the rams with the sheep permanently, allowing continuous mounting and uncontrolled throughout the year. Producers will pretense a reproductive goal of 1.5 farrowing/sheep/year, with a medium result of 1.1 lambing/sheep/ year (73\%), this indicator allows to simplify and unify important information of the milk production systems: lambing interval (LI), duration of lactation and dry period, while it is closer to the value set as a goal, will match a further increase of productivity i.e., more milk and lambs sold by sheep, fact associated with the profitability of the farm(18).

Dairy productivity is 150.1 L/ewe/yr, with a lactation average of $136 \mathrm{~d}$, and 1.6 lambs per ewe per year on the average farm. Dairy productivity is higher than that found in ecological sheep(8); although lower than the data obtained in Castilla y León $(18,22)$, differences mainly due to breed in the case of Castilla y León and the management in ecological sheep.

\section{Infrastructure}

The $85.4 \%$ possesses at least two sheepfold with an average of $11 \mathrm{yr}$ old, due in part to 
información importante de los sistemas de producción de leche como: intervalo entre partos (IEP), duración de la lactancia y duración del periodo seco, mientras más cercano se encuentre al valor establecido como objetivo, se corresponderá con un mayor incremento de la productividad, es decir, más leche y corderos vendidos por oveja, hecho asociado a la rentabilidad de la explotación(18).

La productividad lechera es de 150.1 L/oveja/ año, con una lactación media de 136 días, y 1.6 corderos por oveja/año en la explotación media. La productividad lechera es superior a la encontrada en ovino ecológico en Castilla-La Mancha(8); aunque inferior a los datos obtenidos en Castilla y León(18,22), diferencias debidas principalmente a la raza en el caso de Castilla y León y al manejo en el ovino ecológico.

\section{Infraestructura}

El $85.4 \%$ posee al menos dos apriscos con una antigüedad media de 11 años, consecuencia en parte a la línea de ayudas gubernamentales, para trasladar las explotaciones que se encontraban dentro de los cascos urbanos a las afueras, lo que provocó el proyecto y construcción de numerosas instalaciones(23), resultado similar se reporta en el noroeste de España(22). Predominan los apriscos con solera de tierra, ventilación adecuada, camas de material adecuado (paja) y suficiente. El $74 \%$ de los explotaciones dispone de energía eléctrica y el $65 \%$ obtiene agua directamente de un pozo sin tratar (clorado, etc.), la distancia media de acceso a la explotación es de $9 \mathrm{~km}$ y los caminos están en condiciones adecuadas.

Las explotaciones disponen habitualmente de vehículos (84\%), equipo de ordeño $(86 \%)$ y tanque de refrigeración de leche (97\%); resultados superiores a lo reportado en estudios previos de ovino Manchego(24), lo que sugiere la progresiva incorporación de estas tecnologías en la ganadería ovina manchega. No obstante, es inferior a lo señalado en las explotaciones lecheras del noroeste de España(18,22).
Government assistant, for moving farms located from the urban cities to the suburbs, prompting the project and construction of numerous facilities(23); similar results are reported in the Northwest of Spain(22). The sheepfold with stone floor dominates, offers adequate ventilation, suitable and sufficient bedding straw materials. Seventy four (74) percent of the farms have electricity and $65 \%$ get water directly from an untreated well (chlorine, etc.); the media access to the operating distance is $9 \mathrm{~km}$ and the roads are in proper condition.

Dairy farms usually have vehicles (84\%), equipment (86 \%) and milk cooling tank (97\%), results higher to those reported previously(24), which suggests the progressive incorporation of these technologies into the Manchega sheep. However, it is less than stated in the Northwest of Spain dairy farms $(18,22)$.

\section{Social aspects}

The typical farm is managed under the legal framework of physical person (69\%). The producer is $48 \mathrm{yr}$ old, is married, and at least has a son, with expectations of continuity in the activity of $91 \%$ and insured generational change $(74 \%)$, stable and robust aspects to compare them with those offered by other studies in Castilla-La Mancha sheep systems $(8,23)$. The existing legal figure determines the family nature of farms, which have seen a job opportunity in dairy production, under the protection of the PDO "Queso Manchego" and its social and economic benefits ( 4$)$, that favors the continuity and generational change, key aspects of the sustainability of the system(25).

The producers have $24 \mathrm{yr}$ of experience in the activity, which is considered high comparing to the $15.6 \mathrm{yr}$ reported in dairy cattle(26), or 10 $\mathrm{yr}$ reported in dairy sheep(27). In addition, to experience the existing level of training is key to competitiveness, and more than half of the producers have some level of education, noting that $30 \%$ have medium-high studies; favorable 


\section{Aspectos sociales}

La explotación típica se gestiona bajo la figura jurídica de Persona Física (69 \%). El productor tiene 48 años, está casado y al menos tiene un hijo, con una esperanza de continuidad en la actividad del $91 \%$ y relevo generacional asegurado (74 \%), aspectos estables y robustos al contrastarlos con los ofrecidos por otros estudios $(8,23)$. La figura jurídica existente determina el carácter familiar de las explotaciones, que han visto una oportunidad laboral en la producción lechera, bajo el amparo de la DOP "Queso Manchego" y su beneficio social y económico(4), lo que favorece la continuidad y el relevo generacional, aspectos clave en la sostenibilidad del sistema(25).

Los productores cuentan con 24 años de experiencia en la actividad, la que se considera elevada al compararse con los 15.6 años reportada en vacuno lechero(26), o los 10 años registrados en ovino lechero(27). Además de la experiencia el nivel de formación existente es clave en la competitividad, y más de la mitad de los productores disponen de algún nivel de educación, destacando que el $30 \%$ posee estudios medio-alto; condición favorable cuando se planifican los trabajos de pertinencia social, hecho que favorece mayor dinamismo y apertura a los cambios(28). El perfil del productor es similar al descrito en ovino ecológico de CastillaLa Mancha(8), y en vacuno ecológico en el noroeste de España(26), y se observa una profunda mejora del nivel de estudios en Castilla-La Mancha(19).

Asimismo destaca el elevado nivel de asociacionismo, donde el $88 \%$ de los productores están asociados, lo que difiere a lo reportado en otros sistemas ovinos en España(11,18), y similares a los reportados en sistemas caprinos(29). La cultura del asociacionismo favorece la modernización y desarrollo de la ganadería, entendiéndose éste como la unión de los esfuerzos de los productores con intereses similares, para que puedan obtener beneficios en común en las compras de insumos, materias primas y equipos, condition when the work of social relevance are planned, which favors greater dynamism and openness to change(28). Producer profile is similar to that described in ecological sheep(8), and in ecological bovine(26), and there is a profound improvement of the level of studies in Castilla-La Mancha(19).

The high level of associations outstands, where $88 \%$ of producers are associated which differs to that reported in other sheep systems in Spain $(11,18)$, and similar to those reported in goats systems(29). The culture of associations promotes the modernization and development of the livestock, understanding this as a union of the efforts of the producers with similar interests, so that they can obtain benefits in common of inputs purchases, raw materials and equipment, as well as the marketing and distribution of their products or services(14).

\section{Commercialization}

Dairy production is the main activity (1.04 •/ $\mathrm{L})$ and entirely devoted to the elaboration of Manchego cheese with PDO "Queso Manchego". From the structural point of view used long or traditional, commercial channels above the shorts or alternative (Figure 1). The long commercial structure has as principal agent to the processing industry and cooperatives (91\%), those who marketed $84 \%$ through the traditional trade and large areas and $16 \%$ through wholesaler destined for export(30). Only $9 \%$ of farms processes milk to market through short or alternative channel, either by selling direct to the consumer (69\%) or through direct sales to wholesalers (31\%). Fifty (50) percent of large farms and high use of technology make use of the short channel bound for export. The use of short channels is typical of traditional systems with predominance of informal relationships and focuses on niche markets(13), channels mainly favored by the size and geographic dispersion. Consequently, producers assume this function and implement small-scale artisanal cheese in order to transform their own production. 
así como, en la comercialización y distribución de sus productos o servicios(14).

\section{Comercialización}

La producción lechera es la actividad principal $(1.04 \bullet / l)$ y se destinada en su totalidad a la elaboración de queso manchego con DOP "Queso Manchego". Desde el punto de vista estructural se utilizan los canales comerciales largos o tradicionales, por sobre los cortos o alternativos (Figura 1). La estructura comercial larga tiene como agente principal a la industria transformadora y cooperativas ( $91 \%)$, quienes comercializan el $84 \%$ a través del comercio tradicional y las grandes superficies y el $16 \%$ mediante mayorista con destino a la exportación(30). Sólo el $9 \%$ de las explotaciones procesa la leche para comercializar a través del canal corto o alternativo, ya sea mediante la venta directa al consumidor (69 \%) o mediante la venta directa a mayoristas (31\%). El $50 \%$ de las explotaciones grandes y con alto uso de tecnología hacen uso del canal corto con destino a la exportación. La utilización de canales cortos es típica de sistemas tradicionales con predominio de relaciones comerciales informales y se orienta a nichos de mercado(13), canal favorecido principalmente por la dimensión y la dispersión geográfica. En consecuencia, los productores asumen esta función e implantan queserías artesanales de pequeña dimensión a fin de transformar su propia producción.

Perspectiva de la explotación típica

Respecto a la percepción de los productores sobre los principales problemas, valorados mediante una escala Likert, destacan el precio de los alimentos y de la leche con el 84 y $53 \%$ de los productores totalmente de acuerdo que, son los principales problemas, comportamiento similar a otros sectores ganaderos(17). Le siguen el precio del cordero y la disminución de las subvenciones, con 47 y $44 \%$, respectivamente, de los productores totalmente de acuerdo como el segundo problema a enfrentar. Sin embargo, para los productores no adquieren especial relevancia factores tales como los problemas
Figura 1. Canal de comercialización de la leche en las explotaciones de ovinos manchego pertenecientes a la DOP "Queso Manchego"

Figure 1. Milk commercial channels in DOP "Queso Manchego" farms

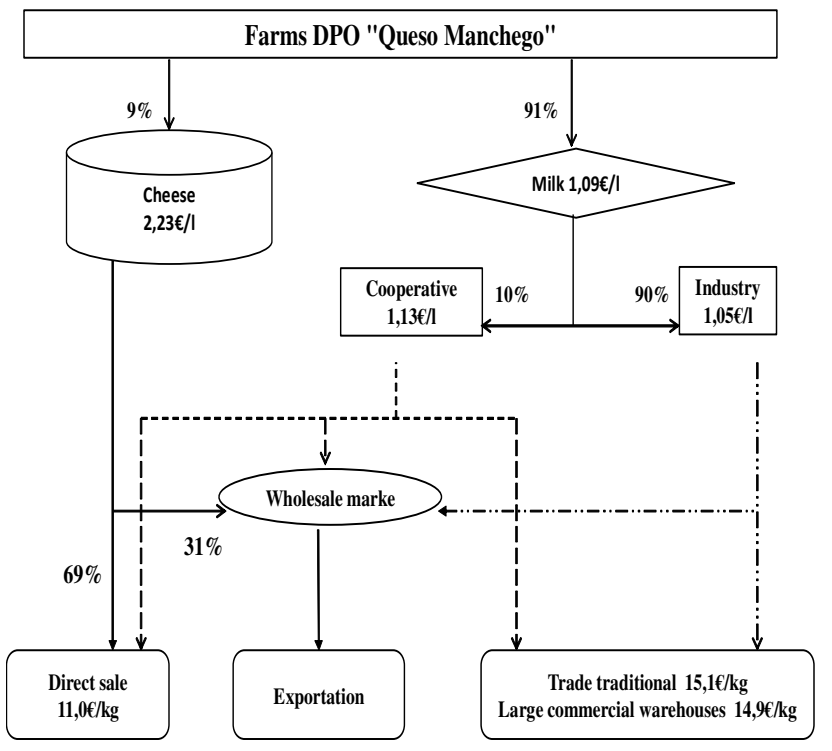

Perspective of the typical farm

As regards the perception of the producers on the main problems, valued using a Likert scale, 84 and $53 \%$ of the producers highlights the price of food and milk, similar to other livestock sectors(17). Producers agree as the second problem to face the lamb price and subsidies reduction, of 47 and $44 \%$, respectively. However, producers do not acquire special relevance to factors such as environmental problems and the decrease in the pasture area, which are closely related to the new regulations of the CAP for the next few years. Perception of the decrease in the area for pasture as an inconvenience, is contradicted by the structural limitations of the sheep-cereal system $(5,6)$.

\section{ANALYSIS OF DIMENSION AND USE OF TECHNOLOGY}

Technical aspects and infrastructure

The proportion of family labor depends on the dimension and use of technology $(P<0.001)$. 
ambientales y la disminución de la superficie de pastos, los cuales están muy relacionados con la nueva normativa de la PAC para los próximos años. La no percepción de la disminución de la superficie de pastos como un inconveniente, se contradice con las limitaciones estructurales del sistema mixto cereal-ovino $(5,6)$.

\section{ANÁLISIS DE LA DIMENSIÓN Y USO DE TECNOLOGÍA}

\section{Aspectos técnicos e infraestructura}

La proporción de mano de obra familiar depende de la dimensión y uso de tecnología $(P<0.001)$. La productividad de la mano de obra difiere $(P<0.001)$ entre las EPQ vs EGD y es independiente del uso de tecnología. La mano de obra es dependiente de la dimensión(11), y en las EGD se observó relación con la carga, ST y diversificación. La baja productividad de la mano de obra surge como consecuencia del carácter pastoril de las explotaciones y de la subutilización de instalaciones y equipo, en general, obsoleta y poco adecuada a la explotación, situación que enfrenta el ganadero a través del incremento de la mano obra(8).
The productivity of the labor force differ $(P<0.001)$ between the SF $v S$ LF and is independent on the use of technology. Labor is dependent on its size(11), and in the LF was observed related to stocking, TA and diversification. The low labor productivity arises as a result of the pastoral nature of farms and underutilization of facilities and equipment, in general, obsolete and little suited to the exploitation, situation faced by the farmer through the increase of the hand work(8).

The proportion of the own area is independent $(P>0.05)$ of size, and dependent $(P<0.001)$ on the use of technology (Table 2 ), similar response is obtained with the agricultural area, indicating that it property promotes the adoption of technology and agriculture(14), mainly by means of the use of best techniques of cultivation, irrigation and fertilization, in order to maximize the harvests yield(6). Similar results to those reported in sheep farms of the Spanish rangelands(11); and Castilla León(18) and on ecological farms sheep(8).

Dependence on external food differs between the categories of dimension $(P<0.01)$ and use of technology $(P<0.001$; Table 2$)$; it is observed

Cuadro 2. Variables cuantitativas (promedio $\pm \mathrm{EE}$ ) y variables cualitativas $(\%)$ de las explotaciones según dimensión y uso de tecnología

Table 2. Quantitative variables (mean $\pm \mathrm{SE}$ ) and qualitative variables (\%) of farms according to size and use of technology

\begin{tabular}{|c|c|c|c|c|}
\hline \multirow[b]{2}{*}{ Variable } & \multicolumn{2}{|c|}{ Size } & \multicolumn{2}{|c|}{ Use of technology } \\
\hline & Small & Large & Medium & High \\
\hline Family labor, \% & $72.7 \pm 3.7^{\star \star \star}$ & $43.4 \pm 3.6^{\star \star *}$ & $74.3 \pm 3.7^{\star \star *}$ & $41.8 \pm 3.8^{\star *}$ \\
\hline Hand labor productivity (UL/AWU) & $36.1 \pm 2.1^{* * *}$ & $53.6 \pm 2.1^{* * *}$ & $47.0 \pm 2.0$ & $42.6 \pm 2.2$ \\
\hline Own area, \% & $12.5 \pm 3.7$ & $18.7 \pm 3.6$ & $8.1 \pm 3.5^{\star \star \star}$ & $23.1 \pm 3.8^{* * *}$ \\
\hline Agricultural area, \% & $14.5 \pm 3.1$ & $20.4 \pm 3.1$ & $10.7 \pm 3.0^{* *}$ & $24.3 \pm 3.2^{\star *}$ \\
\hline Feed external dependency, \% & $67.3 \pm 2.3^{* *}$ & $53.7 \pm 3.3^{* *}$ & $70.5 \pm 3.2^{* * *}$ & $50.5 \pm 3.5^{\star * *}$ \\
\hline Lambing season, $\mathrm{n}$ & $2.7 \pm 0.18^{\star \star \star}$ & $3.9 \pm 0.18^{* \star \star}$ & $2.6 \pm 0.17^{\star \star \star}$ & $4.1 \pm 0.19^{\star \star *}$ \\
\hline Milk production, L/ewe/year & $138.7 \pm 6.4$ & $153.5 \pm 6.2$ & $135.9 \pm 6.1^{*}$ & $156.3 \pm 6.5^{\star}$ \\
\hline Lactation, d & $129.1 \pm 4.0^{*}$ & $141.7 \pm 3.8^{*}$ & $127.8 \pm 3.7^{\star \star}$ & $142.9 \pm 4.1^{* *}$ \\
\hline Producer experience, yr & $28.4 \pm 1.5^{\star}$ & $22.9 \pm 1.4^{*}$ & $26.3 \pm 1.4$ & $25.0 \pm 1.6$ \\
\hline
\end{tabular}

$\mathrm{SE}=$ Standard error. $\mathrm{UL}=$ units of livestock; $\mathrm{AWU}=$ Annual works units. ${ }^{* * *}(P<0.001) ;{ }^{* *}(P<0.01) ;{ }^{*}(P<0.05)$. 
La proporción de superficie propia es independiente $(P>0.05)$ de la dimensión, y dependiente $(P<0.001)$ del uso de tecnología (Cuadro 2), respuesta similar se obtiene con la superficie agrícola, lo que indica que la propiedad favorece la adopción de tecnología y la actividad agrícola(14), principalmente por el uso de mejores técnicas de cultivo, riego y fertilización, con el fin de maximizar el rendimiento de las $\operatorname{cosechas}(6)$. Resultados similares a los reportados en explotaciones ovinas de la Dehesa(11); y de Castilla León(18) y en explotaciones ecológicas de ovinos(8).

La dependencia de alimentos externos difiere entre las categorías de dimensión $(P<0.01)$ y uso de tecnología $(P<0.001$; Cuadro 2$)$, se observa que las EPQ y las EUMT registran la mayor dependencia de insumos externos debido a una actividad agrícola de baja producción. En el caso de las EGD y EUAT, donde existe una importante superficie dedicada a la agricultura, la dependencia de insumos externos es consecuencia del mayor número de animales, similar a lo reportado en explotaciones ovinas del noroeste de España(18).

La dimensión y uso de tecnología afectan $(P<0.01)$ el sistema de alimentación utilizado por las explotaciones. Las EPQ (58 \%) y EUMT (55 \%) emplean como sistema de alimentación el suministro de pienso y forraje por separado sin considerar el nivel productivo, a diferencia de las EGD (61 \%) y EUAT (79 \%) que utilizan como sistema de alimentación una mezcla de forrajes y subproductos industriales, además de pienso acorde al nivel productivo de los animales. Este sistema de alimentación permite automatizar el suministro de la dieta a los animales favoreciendo un mayor aprovechamiento de la mano de obra.

La planificación de la reproducción depende $(P<0.01)$ de la dimensión y del uso de tecnología (Cuadro 2), las EGD y EUAT planifican en promedio cuatro cubriciones con 1 mes de duración y monta controlada. No se obtuvieron diferencias $(P>0.05)$ en cuanto al índice that the SF and the FMUT recorded an increased dependence on external inputs due to an agricultural activity of low production. In the case of the LF and FHUT, where there is an important area dedicated to agriculture, the dependence on external inputs is a consequence of the higher number of animals, similar to that reported in sheep farms in the Northwest of Spain(18).

The dimension and use of technology affect $(P<0.01)$ the feeding system used by farms. The SF (58 \%) and FMUT (55 \%) used as feeding system, supply of feed and forage separately without considering the production level, unlike the LF (61\%) and FHUT (79\%) which used a mixture of forage and industrial by-products, besides concentrate food according to the production level of the animals. This feeding system allows to automate the animals diet supply, favoring a greater use of labor.

The planning of reproduction depends on $(P<0.01)$ dimension and the use of technology (Table 2), the LF and FHUT plan an average four mating seasons with 1 month's duration and controlled matings. There were no differences $(P>0.05)$ in the reproductive index, $\mathrm{CI}$, and reproductive efficiency in the two factors, response that can be explained by the increased production of milk the LF and FHUT(18). The level of technology affects $(P<0.05)$ duration of lactation and milk production $(P<0.01)$, which also depends on the dimension $(P<0.05$; Table 2$)$, in response to the realization of milk control which allows a better knowledge and control of animals and that in the long term allows to select more productive animals, with the consequent increase in the milk production per lactation, results observed in the present study.

\section{Social aspects}

The years in the livestock activity (Table 2), differ $(P<0.05)$ between the SF vs LF. The level of studies and associations are dependent on the size and use of technology $(P<0.001)$, 
reproductivo, IEP y eficiencia reproductiva en los dos factores, respuesta que puede ser explicada por la mayor producción de leche de las EGD y EUAT(18). El nivel tecnológico afecta $(P<0.05)$ la producción de leche y duración de la lactancia $(P<0.01)$, la cual también depende de la dimensión $(P<0.05$; Cuadro 2$)$, en respuesta a la realización del control lechero que permite un mayor conocimiento y control de los animales, y que a largo plazo permite seleccionar los animales más productivos, con el consecuente incremento en la producción de leche por lactancia, resultado observado en el presente estudio.

\section{Aspectos sociales}

Los años en la actividad ganadera (Cuadro 2), difieren $(P<0.05)$ entre las EPQ vs EGD. El nivel de estudios y asociacionismo son dependientes de la dimensión y uso de tecnología $(P<0.001)$, resultados que indican que los productores con menos tiempo en la cría ovina y mayor nivel educativo se apoyan en más tecnologías para la gestión de las EGD. Respuesta que puede deberse a la disposición de transformar esquemas tradicionales en procesos sistemáticos, que permiten mayor apertura a la incorporación de tecnologías de producción animal(28).

La explotación de ovino manchego responde, a la calificación propuesta por la $\mathrm{FAO}(31)$, como sistema mixto de economía familiar, con amplia distribución en el mundo. Recientes investigaciones $(5,31,32)$, las denominan: explotaciones extensivas, familiares, múltiples, de bajos insumos y generalmente de pequeña escala.

El sistema analizado muestra diferencias acordes con su dimensión y el uso de tecnología, similar a lo indicado en explotaciones de ovejas Chios(33). Donde las explotaciones pequeñas y con bajo uso de tecnología son sistemas productivos familiares, dirigidos a aprovechar los recursos naturales con baja tecnificación y escala y su objetivo es distinto al de la lechería intensiva(7), y las explotaciones grandes y con elevado nivel tecnológico se orientan a la results that indicate that the producers with less time in the sheep breeding and higher educational level, rely on technologies for the management of the LF. Response to the availability to transform traditional schemes in systematic processes that allow greater openness for incorporating technologies on animal production(28).

The exploitation of Manchega sheep correspond to the rating proposed by $\mathrm{FAO}(31)$, as a mixed system of economy family, with wide world distribution. Recent research $(5,31,32)$ called them: extensive farms, family, multiple, lowinput and usually small scale.

The analyzed system displays differences according to their dimension and the use of technology, similar to the Chios sheep farms(33). Where family production systems, aimed to exploit natural resources at small scale and with low use of technology and its objective differs from that of intensive dairying(7), but large farms showing a high use of technology and oriented to maximum productivity and seeking maximum benefit(34). Differences that pastoral production tends to decrease cost and its main objective is to generate selfemployment worth excluded social segment of other labor markets and low-opportunity cost(7).

The exploitation of Manchega sheep allows to transform a rigid production (specialized intensive dairying) in an extensive activity with some elasticity, due among other factors, to their low level of investment, so it can be combined as a complement from other productions of the system $(5,8,34)$. In such a way that the producer as a consequence of climatic and structural constraints adjusts the herd management to more favorable conditions $(5,6)$, similar performance to that described in dual purpose cattle, which gives it a competitive advantage(35).

Thus the PDO, favors the conservation and maintenance of local breeds and their systems by manufacturers and processors(4) and the 
máxima productividad y máximo beneficio(34). Diferencias que indican que la producción pastoril tiende al mínimo costo y su objetivo principal es generar autoempleo digno de un segmento social excluido de otros mercados laborales y con bajo costo de oportunidad(7).

La explotación del ovino manchego permite transformar una producción rígida (lechería intensiva especializada) en una actividad extensiva con cierta elasticidad, debido entre otros factores a su bajo nivel de inversiones, por lo que puede combinarse mediante complementación con las restantes producciones del sistema(5,8,34). De tal modo que el productor debido a las limitaciones climáticas y estructurales ajusta el manejo del rebaño a las condiciones más favorables $(5,6)$, comportamiento similar al descrito en doble propósito bovino, lo que le confiere una ventaja competitiva(35).

Así la DOP, favorece la conservación y mantenimiento de las razas locales y sus sistemas, por medio de empresas productoras y transformadoras(4) y el desarrollo de la economía agrícola en la Comarca la Mancha y la sostenibilidad del mundo rural(11). La DOP es una marca de calidad que potencia productos locales de calidad diferenciada, aunque las empresas pueden adoptar otras estrategias sustentables igualmente competitivas, tales como marcas de calidad e indicaciones geográficas protegidas $(4,36)$.

El estudio permite proponer la mejora de prácticas de manejo y el diseño de estrategias de futuro, tales como la utilización de la identificación y registros en la toma de decisiones; la mejora del pastoreo, utilización de reservas forrajeras (heno - silo), considerar la utilización de los subproductos de la zona en el racionamiento de la alimentación y mejorar la higiene y limpieza en las instalaciones.

Por tanto, el agrosistema mixto agriculturaganadería, base de la DOP "Queso Manchego" es una herramienta estratégica de un sistema productivo sustentable bajo un modelo de development of the agricultural economy in la Mancha region and the sustainability of rural areas(11). The PDO is a mark of quality that enhances differential quality local products, although companies may adopt other equally competitive sustainable strategies, such as quality marks and protected geographical indicators $(4,36)$.

The study makes it possible to propose the improvement of managerial practices and the design of future strategies such as the use of the identification and records in decision-making; the improvement of grazing, use of forage reserves (hay-silage), consider the use of the by-products of the zone in the rationing of food and improving the hygiene and cleanliness of installations.

Therefore, the agriculture-livestock mixed agro system, base of the PDO "Queso Manchego" means a strategic tool of a sustainable production system under a model of productionfriendly environment that promotes the sustainable development of rural communities.

\section{CONCLUSIONS AND IMPLICATIONS}

Milk production of Manchega sheep responds to a mixed system (crop-livestock) with multiple products (milk, lamb and cheese), with a family character, low-external input and which generates three direct jobs. Marketing is both, by long and short commercial channels. The price of inputs and products is the main problem to face. Operations differ according to the dimension and the use of technology, with farms ranging from small extensive to large intensive. The exploitation of Manchego sheep has among its competitive advantages the diversification of risk, the use of local breeds and inputs, and moderate elasticity between activities, low investment and the production of a product identified worldwide for their quality, allowing to contribute to the preservation of the ecosystems and the endogenous and sustainable development of the area. Again the incorporation of farms to the "PDO Queso 
producción respetuoso con el medio ambiente que favorece el desarrollo sostenible de las comunidades rurales.

\section{CONCLUSIONES E IMPLICACIONES}

La producción lechera del ovino manchego responde a un sistema mixto (agriculturaganadería) con producción múltiple (leche, cordero y queso), con un carácter familiar, de bajos insumos externos y que genera de modo directo tres puestos de trabajo. La comercialización se realiza tanto por canales comerciales largos y cortos. El precio de los insumos y de los productos constituye el principal problema a enfrentar. Las explotaciones difieren de acuerdo a la dimensión y el uso de tecnología, con explotaciones que van desde pequeñas extensivas hasta las grandes intensivas. La explotación del ovino manchego tiene entre sus ventajas competitivas la diversificación del riesgo, la utilización de razas e insumos locales, moderada elasticidad entre actividades, bajo nivel de inversiones y la producción de un producto identificado a nivel mundial por su calidad, lo que permite contribuir a la preservación del ecosistemas y al desarrollo endógeno y sostenible de la zona. Asimismo la incorporación de las explotaciones a la DOP Queso Manchego", conlleva una serie de ventajas directas para los productores, como la participación en programas de apoyo en la mejora genética y de calidad higiénico-sanitaria de la leche. Asimismo estratégicamente conlleva una apuesta por la internacionalización de la producción, la valorización del producto, la defensa del agrosistema y la economía de los productores de Castilla-La Mancha.

\section{AGRADECIMIENTOS}

Se agradece al Consejo de Desarrollo Científico y Humanístico de la Universidad Central de Venezuela (CDCH-UCV), por la beca para la realización de los estudios de Doctorado en la Universidad de Córdoba y al Proyecto de
Manchego", imply a number of direct benefits for producers, such as participation in support programs, in genetic improvement and health hygienic quality of milk. It also strategically entails a commitment to the internationalization of production, the valorization of the product, the defense of the agro system and the economy's producers from Castilla-La Mancha.

\section{ACKNOWLEDGMENTS}

Thanks to the Council of Scientific Development and Humanistic of the Universidad Central of Venezuela (CDCH-UCV), for the scholarship to carry out doctoral studies at the University of Cordoba and the project's Fundamental research oriented resources and agricultural technologies in coordination with the communities autonomous of the Instituto Nacional Española de Investigación y Tecnología Agraria y Alimentaria (RTA2011 - 00057 - C02 - 02), for their economic contribution in the implementation of activities.

End of english version

Investigación Fundamental orientada a los recursos y tecnologías agrícolas en coordinación con las Comunidades Autónomas del Instituto Nacional Española de Investigación y Tecnología Agraria y Alimentaria (RTA2011 - 00057 -C0202), por su aporte económico en la ejecución de las actividades.

\section{LITERATURA CITADA}

1. MAGRAMA. Ministerio de Agricultura Alimentación y Medio Ambiente. Anuario estadísticas 2011. http:// www.magrama.gob.es/es/estadistica. Consultado Ene 1, 2013.

2. AGRAMA. Asociación Nacional de Criadores de Ganado Ovino Selecto de Raza Manchega. Programa de mejora de la raza ovina Manchega: http://www.agrama.org/.pdf Consultado Ene 1, 2013. 


\section{CARACTERIZACIÓN DE EXPLOTACIONES OVINAS MANCHEGAS}

3. Pillet F, Cañizares MC, Ruíz AR, Plaza J, Santos JF, Martínez HS. Fuentes para la aplicación de la estrategia territorial europea en Castilla-La Mancha. Estud Geogr 2007;68(263):627-651.

4. Bertozzi L. Designation of origin: Quality Food and specification. Food Qual 1995;(6):143-147.

5. Caballero R. Typology of cereal-sheep farming systems in Castilla-La Mancha south-central Spain. Agr Syst 2001;(68):215-232.

6. Caballero R. Stakeholder interactions in Castile-La Mancha. Spain's cereal-sheep system. Agric Human Values 2009;(26):219-231.

7. Toro-Mujica P, García A, Gómez-Castro G, Acero R, Perea J, Rodríguez-Estévez V, Aguilar C, Vera R. Technical efficiency and viability of organic dairy sheep farming systems in a traditional area for sheep production in Spain. Small Ruminant Res 2011;(100):89-95.

8. Toro-Mujica P, García A, Goméz-Castro G, Perea J, RodríguezEstévez V, Angón E. Organic dairy sheep farms in southcentral Spain: Typologies according to livestock management and economic variables Small Ruminant Res 2012;(104):2836.

9. de Rancourt M, Fois N, Lavín M, Tchakérian E, Vallerand F. Mediterranean sheep and goats production: an uncertain future. Small Ruminant Res 2006;(62):167-179.

10. Riedel JL, Casasús I, Bernués A. Sheep farming intensification and utilization of natural resources in a Mediterranean pastoral agro-ecosystem. Livest Sci 2007;(111):153-163.

11. Gaspar P, Escribano M, Mesías F, Rodríguez de Ledesma A, Pulido F. Sheep farms in the Spanish rangelands (dehesas): Typologies according to livestock management and economic indicators. Small Ruminant Res 2008;(74):52-63.

12. García-Díaz LK, Mantecón A, Sepúlveda W, Maza M. Producción de leche ovina como alternativa de negocio agropecuario: modelo de producción en Castilla y León (España). Rev Mex Agronegocio 2012;16(31):6-18.

13. Trejo-Telléz BI, de los Rios-Carmenado I, Figueroa-Sandoval B, Gallego-Moreno, Morales-Flores FJ. Análisis de la cadena de valor del queso Manchego en Cuenca. España. Rev Mex Cienc Agr 2011;2(4):545-557.

14. Valerio D, García A, Perea J, Acero R, Gómez-Castro G. Caracterización social y comercial de los sistemas ovinos y caprinos de la región noroeste de República Dominicana. Interciencia 2009;34(9):637-644.

15. Cuevas-Reyes V, Baca del Moral J, Cervantes-Escoto F, Espinosa-García J, Aguilar-Ávila J, Loaiza-Meza A. Factores que determinan el uso de innovaciones tecnológicas en la ganadería de doble propósito en Sinaloa. México. Rev Mex Cien Pecu 2013;4(1):31-46.

16. SPSS. Statistical Package for the Social Sciences. Guía breve de SPSS 15.0. SPSS. Inc., Chicago. 2006.

17. Perea J, Giorgis A, García A, Larrea A, Gómez-Castro G, Mata H. Estructura de las explotaciones lecheras de La Pampa (Argentina). Rev Cient-Fac Cienc V 2011;21(3): 247255.

18. Milán M, Caja G, González-González R, Fernández-Pérez A, Such $X$. Structure and performance of Awassi and Assaf dairy sheep farms in nothwestern Spain. J Dairy Sci 2011;(94):771-784.

19. Oliver F, Pérez-Guzmán MD, Madero S, Montoro V, Aguado M, Gil P. Características sociales y de infraestructura en las ganaderías de pequeños rumiantes de Castilla-La Mancha: Influencia en la continuidad generacional. En: Ciria J, Asenjo B editores. XXIV Jornadas Científicas Jornadas Científicas y III Jornadas Internacionales de Ovinotecnia y Caprinotecnia. Soria, España 1999:551-554.

20. Pardos L, Maza M, Fantova E, Sepúlveda W. The diversity of sheep production systems in Aragón (Spain): characterisation and typification of meat sheep farms. Span J Agric Res 2008;6(4):497-507.

21. Molle G, Decandia M, Cabiddu A, Landau S, Cannas A. An update on the nutrition of dairy sheep grazing Mediterranean pastures. Small Ruminant Res 2008;(77):93-112.

22. Riveiro J, Mantecón A, Álvarez C, Lavin P. A typological characterization of dairy Assaf breed sheep farms at NW of Spain base on structural factor. Agr Syst 2013;(120):27-37.

23. Montoro $V$, Vicente J, Rincón E, Pérez-Guzmán MD, Gallego R, Rodríguez JM, Arias R, Garde JJ. Actualidad de la producción de ovino lechero en la Comarca Montes Norte de Ciudad Real: I. Estructura de las explotaciones. En: Abecia A, et al editores. XXXII Jornadas Científicas y XI Jornadas Internacionales de Ovinotecnia y Caprinotecnia. Mallorca, España. 2007:133-136.

24. Pérez-Guzmán MD, Seldas M, Gallego L, Altares S, Oliver F, González M, Montoro V. Aspectos socioeconómicos de las ganaderías de ovino manchego en Castilla-La Mancha. En: Beltrán de Heredia I, Urarte E editores. XXIII Jornadas Científicas de la Sociedad Española de Ovinotecnia y Caprinotecnia. Vitoria-Gasteiz, España 1998:233-236.

25. Ripoll-Bosch $R$, Díez-Unquera $B$, Ruiz $R$, Villalba $D$, Molina $E$, Joy $M$, Olaizola $A$, Bernués $A$. An integrated sustainability asessment of mediterranean sheep farms with different degrees of intensification. Agr Syst 2012;(105):46-56.

26. Perea J, Mata H, García A, Castaldo A, Gómez.Castro G, Acero R. Aspectos técnicos y sociales de las explotaciones ecológicas bovinas lecheras del noroeste de España. Rev Cient-Fac Cienc V 2010;20(6):633-639.

27. Gelasakis A, Valergakis G, Fortomaris P, Arsenos G. Farm conditions and production methods in Chios sheep flocks. J Hell Vet Med Soc 2010;61(2):111-119.

28. Morantes M, Rondón Z, Colmenares O, Ríos de Álvarez L, Zambrano C. Análisis descriptivo de los sistemas de producción con ovinos en el municipio San Genaro de Boconito (Estado Portuguesa. Venezuela). Rev Cient-Fac Cienc V 2008;28(5):556-561.

29. Gaspar P, Escribano A, Mesías F, Escribano M. Pulido A. Goat systems of Villuercas-Ibores area in SW Spain: Problems and perspectives of traditional farming systems. Small Ruminant Res 2011;(97):1-11.

30. CRDOQM. Consejo Regulación de Origen Queso Manchego. Fuerte incremento de la exportación de Queso Manchego. http://www.quesomanchego.es/noticias/noticia-4. Consultado Ene 1, 2013.

31. Robinson T, Thornton P, Franceschini G, Kruska R, Chiozza F, Notenbaert A, et al. Global livestock production systems. Rome. Food and Agriculture Organization of the United Nations (FAO) and International Livestock Research Institute (ILRI). 2011. http://www.fao.org/docrep/014/i241e00.htm. Consultado Sept 15, 2013.

32. Hemme T, García O, Khan A. Estudio de la producción de leche en Bangladesh con atención especial a los pequeños productores. En: Food and Agriculture Organization of the 
José Rivas, et al. / Rev Mex Cienc Pecu 2014;5(3):291-306

United Nations editor. Iniciativa de políticas pecuarias en favor de los pobres (PPLPI). 2013. http://www.fao.org/ag/ pplpi.pdf. Consultado Ene 15, 2014.

33. Gelasakis A, Valergakis G, Arsenos G, Banos G. Description and typology of intensive Chios dairy sheep farms in Greece. J Dairy Sci 2012;(95):3070-3079.

34. Angón E, García A, Perea J, Acero R, Toro-Mújica P, Pacheco $\mathrm{H}$, González A. Eficiencia técnica y viabilidad de los sistemas de pastoreo de vacunos de leche en la Pampa. Argentina. Agrociencia 2013;47(5):443-456.
35. Urdaneta, F. Mejoramiento de la eficiencia productiva de los sistemas de ganadería bovina de doble propósito (TaurusIndicus). Archivos Latinoamericano de Producción Animal 2009; 17:109-120.

36. Paz-Cafferata J, Pomareda C. Indicaciones geográficas y denominaciones de origen en Centroamérica: situación y perspectivas. Centre for Trade and Sustainable Development (ICTSD). Geneva, Switzerland; 2009. http://ictsd.org/ downloads/2012/02/indicaciones-geograficas-ydenominaciones-de-origen-en-centroamerica.pdf Consultado Mar 28, 2014. 